\title{
Predictors of Number of Healthcare Professionals Consulted by Individuals with Mental Disorders or High Psychological Distress
}

\author{
Béatrice Simo ${ }^{1}$, Jean Caron ${ }^{2,3}$, Jean-Marie Bamvita ${ }^{2}$, Guy Grenier ${ }^{2}$ and \\ Marie-Josée Fleury 2,3,*iD \\ 1 École de santé publique, Université de Montréal, 7101 av. du Parc, Montréal, QC H3X1X9, Canada \\ 2 Research Centre, Douglas MH University Institute, 6875 LaSalle Blvd, Montreal, QC H4H 1R3, Canada \\ 3 Department of Psychiatry, McGill University, 1033, Pine Avenue West, Montreal, QC H3A 1A1, Canada \\ * Correspondence: flemar@douglas.mcgill.ca
}

Received: 12 July 2019; Accepted: 16 August 2019; Published: 21 August 2019

\begin{abstract}
This study assesses the contribution of predisposing, enabling, and needs factors and related variables that predicted the number of healthcare professionals consulted for mental health reasons among 746 individuals with mental disorders and high psychological distress. The data were drawn from the third (T3) and fourth data collection periods (T4) of a longitudinal study conducted in a Quebec/Canada epidemiological catchment area. Hierarchical linear regression was performed on the number of types of healthcare professionals consulted in the 12 months prior to T4. Predictors were identified at T3, classified as predisposing, enabling, and needs factors (i.e., clinical and related variables) according to the Andersen Behavioral Model. Three needs factors were associated with the number of types of healthcare professionals consulted: Post-traumatic stress disorder, stressful events, and marginally suicide ideation. Three enabling factors: Having a family physician, previous use of mental health services, and employment status were also related to the dependent variable. Poor self-perception of mental health status was the only predisposing factor retained. While needs factors were the main predictors of the number of types of healthcare professionals consulted, enabling factors may reduce the influence of needs factors, by the deployment of various strategies that facilitate continuous and appropriate care.
\end{abstract}

Keywords: predictors; number of diversified healthcare professionals consulted; needs; mental disorders; high psychological distress

\section{Introduction}

Mental disorders (MD) represent a challenge to the healthcare system due to their high prevalence, costs, and burden of disability, while negatively impacting quality of life for affected individuals and families [1,2]. Recurring MD and physical comorbidity are also common [3,4], leading many individuals to seek extensive and diversified care [5]. According to previous studies, as many as $70 \%$ of individuals affected by MD who use services consult professionals in primary care settings for prevalent mental health $(\mathrm{MH})$ conditions such as anxiety, mood, and substance use disorders [6,7], while approximately $36 \%$ of individuals with MD seek care from general practitioners and $\mathrm{MH}$ specialists [5]. General practitioners at the entry point to primary care are largely responsible for care co-ordination and patterns of service use. Patients perceive help received from general practitioners in combination with $\mathrm{MH}$ specialists as highly effective [8]. For instance, psychotherapy provided by a psychologist is commonly recommended for the treatment of common MD (e.g., depression, anxiety), with medication provided by a general practitioner [9]. Case managers, often nurses or social 
workers, are involved with patient follow-up in many best-practice models. They oversee medication adherence and healthy living practices as well as crisis management $[10,11]$. General practitioners may also request consultations with psychiatrists for assistance in establishing diagnoses or prescribing treatments for MD, particularly in complex cases or recurrent illness [12].

Collaborative care models have been identified as particularly successful in delivering integrated medical and MH care $[13,14]$, with demonstrated effectiveness for improving access to care, patient outcomes and satisfaction, and for controlling costs [15]. Effective management of MH patients involves close collaboration between general practitioners and $\mathrm{MH}$ professionals working in primary care settings (e.g., nurses, psychologists, social workers) and with psychiatrists from specialized care settings $[9,16]$. In publicly funded health systems, as in Canada, individuals with $\mathrm{MH}$ problems are generally seen first in primary care settings by general practitioners or family physicians, then referred to $\mathrm{MH}$ specialists or other healthcare professionals as needed. In Quebec, collaborative care models in MH were vigorously promoted in the context of the $2005 \mathrm{MH}$ Action Plan and reinforced in the new MH Action Plan of 2015. In this context of MH system transformation, it may be useful to identify variables that predict the number of types of healthcare professionals consulted for $\mathrm{MH}$ reasons. While studies abound on the frequency of $\mathrm{MH}$ service use, and emergency department use in particular [17-19], relatively few studies have addressed MH service use with a focus on the number of different types of healthcare professionals consulted [5,20].

Considerable research on $\mathrm{MH}$ service utilization has been guided by the Andersen Behavioral Model [21]. This model represents the dominant framework for understanding treatment seeking and identifying predictors of service utilization [22]. According to this model, variables that influence healthcare service utilization, including MH services, may be grouped according to three types of factors: (1) Predisposing factors, including individual socio-demographic characteristics that predate the onset of illness (e.g., age, civil status), and health beliefs (e.g., attitudes, values, and knowledge related to personal health and health services) that may inform perceptions of need and future service use [21]; (2) enabling factors, or resources that facilitate service access (e.g., having a family physician, previous use of $\mathrm{MH}$ services); and (3) needs factors, including clinical variables such as diagnoses and other needs variables such as those related to functional disability [21,22]. The Andersen Behavioral Model has the great advantage of including a broad range of variables that may facilitate or hinder healthcare service utilization and specifying the relative influence of these factors. The results of most studies suggest that needs factors account for most health service use [21].

Concerning predisposing factors, previous research has found a positive association between age and use of both psychiatrists and general medical professionals [23]. A Canadian study with a community-based adult sample found that women were more likely than men to consult general practitioners and psychologists; or general practitioners and other health professionals (e.g., nurse, social worker, counsellor) with the exception of psychiatrists [24]. Concerning enabling factors, individuals who enjoyed excellent relationships with their neighbors, consulted relatively higher numbers of types of professionals for $\mathrm{MH}$ problems [5]. Regarding needs factors, individuals with previously diagnosed depression were more likely to seek help from both a general practitioner and psychiatrist; while having more than one MD was associated with more types of professionals consulted [5]. Psychological distress stood out in one study as the best single predictor for all types of healthcare consultations (general practitioners, MH specialists, other healthcare professionals) [25]. Participants with unmet MH needs also were more likely to seek help from general practitioners, psychologists, or other professionals (e.g., psychiatrists, nurses, social workers) [26].

Previous studies on MH service use have mainly focused on samples of individuals with MD only, even though an appreciable proportion of MH service users have subthreshold MD and needs that may differ from those of individuals who meet the criteria for a diagnosed MD $[7,27,28]$. In one systematic review that analyzed the results of 18 epidemiological studies including 48,214 participants, the prevalence of subthreshold generalized anxiety disorder (GAD) was twice that of diagnosed GAD; however, people with subthreshold GAD had more persistent symptoms than those with anxiety 
disorders, which caused suffering, psychosocial, and work-related impairment. They also were at a greater risk for developing threshold GAD and other anxiety, mood, and substance use disorders [29]. In addition, having an undiagnosed MD was a significant predictor of lifetime hospitalization, lifetime MD without current symptoms, suicide attempts, high psychological distress, and other significant disability [27].

In order to form a better picture of individuals in need of MH services, it may be useful to investigate $\mathrm{MH}$ service utilization among individuals without a diagnosis, but who are at high risk for MD [30]. Accordingly, this study focused on both individuals with a diagnosed MD and those with high psychological distress as measured by: (1) Symptoms similar to those associated with common MD including depression and anxiety [31]; (2) conditions likely to evolve into MD if left untreated; and (3) conditions associated with high levels of functional impairment [32]. MH service utilization studies that include participants with high psychological distress at risk for developing MD, as well as diagnosed individuals, also conform to $\mathrm{MH}$ policies encouraging early intervention [33,34]. Thus, using the Andersen model, this study aims: (1) To assess the relative contribution of predisposing, enabling, and needs factors on the number of types of healthcare professionals consulted for $\mathrm{MH}$ reasons and (2) to identify predictors of a greater diversity of healthcare professionals consulted in a sample of both individuals with diagnosed MD and those with high psychological distress. As needs factors were mainly associated with health service use in previous studies, we hypothesized that individuals with more serious needs would seek help from a greater variety of $\mathrm{MH}$ professionals.

\section{Method}

\subsection{Study Design and Setting}

This study is based on a subsample from a longitudinal population-based cohort study, conducted in an epidemiological catchment area in Southwest Montreal, Quebec (Canada), with a population of 269,720 distributed among six neighborhoods. Data for this specific study (the subsample) included the two last data collections from the full longitudinal study (T3, T4). The area includes a major psychiatric hospital offering specialized services for serious and complex MD, and two community health and social service centers that deliver primary MH care. Numerous private clinics employ general practitioners and psychologists, while community organizations offer supportive services such as crisis centers, day centers, and self-help groups for individuals with $\mathrm{MH}$ problems and their families.

\subsection{Selection Criteria and Study Population}

Study participants had to be between 15 and 65 years of age and live within the catchment area. A geographically representative sample with socio-economic and other characteristics proportional to those of the general population was sought. A random sample of 3408 home addresses was initially selected for recruitment purposes. In order to improve the recruitment process, this initial list was extended to include a range of 14 neighboring addresses for door-to-door recruitment [35]. Interviews were scheduled with individuals who agreed to participate either at home or at another designated location. Trained interviewers administered questionnaires to participants. The duration of interviews ranged from 90 to $135 \mathrm{~min}$ depending on whether or not participants had positive signs of MD and/or used MH services. Each participant signed a consent form prior to the interview. The anonymity of participants was guaranteed, and data were kept in a place accessible only to project researchers. Telephone contacts were made every six months encouraging participants to participate in the subsequent data collection periods. The ethics review board of a MH institute approved the multi-site protocol.

The first data collection period (T1: June 2007-December 2008) included N = 2434 study participants. Three additional data collection periods followed at two-year intervals (T2: June 2009-December 2010; T3: June 2011-December 2012; T4: June 2013-December 2015); they are summarized in Figure 1. The response rate for this longitudinal cohort was: $74.9 \%$ at $\mathrm{T} 2,72 \%$ at 
$\mathrm{T} 3$, and $80 \%$ at $\mathrm{T} 4$. These response rates were slightly higher than those in comparable longitudinal epidemiological studies (69\% to $76 \%$ for other two to five year studies) [36,37]. Most dropout between data collection periods involved lower participation by younger or materially deprived individuals and those diagnosed with substance use disorders. Further details on selection criteria and sample characteristics have been published elsewhere [5,35]. At the fourth data collection period, the mean age of participants $(\mathrm{N}=1871)$ was 44.72 years (SD: 13.86$) ; 60 \%$ were female, and a small majority lived alone (52\%).

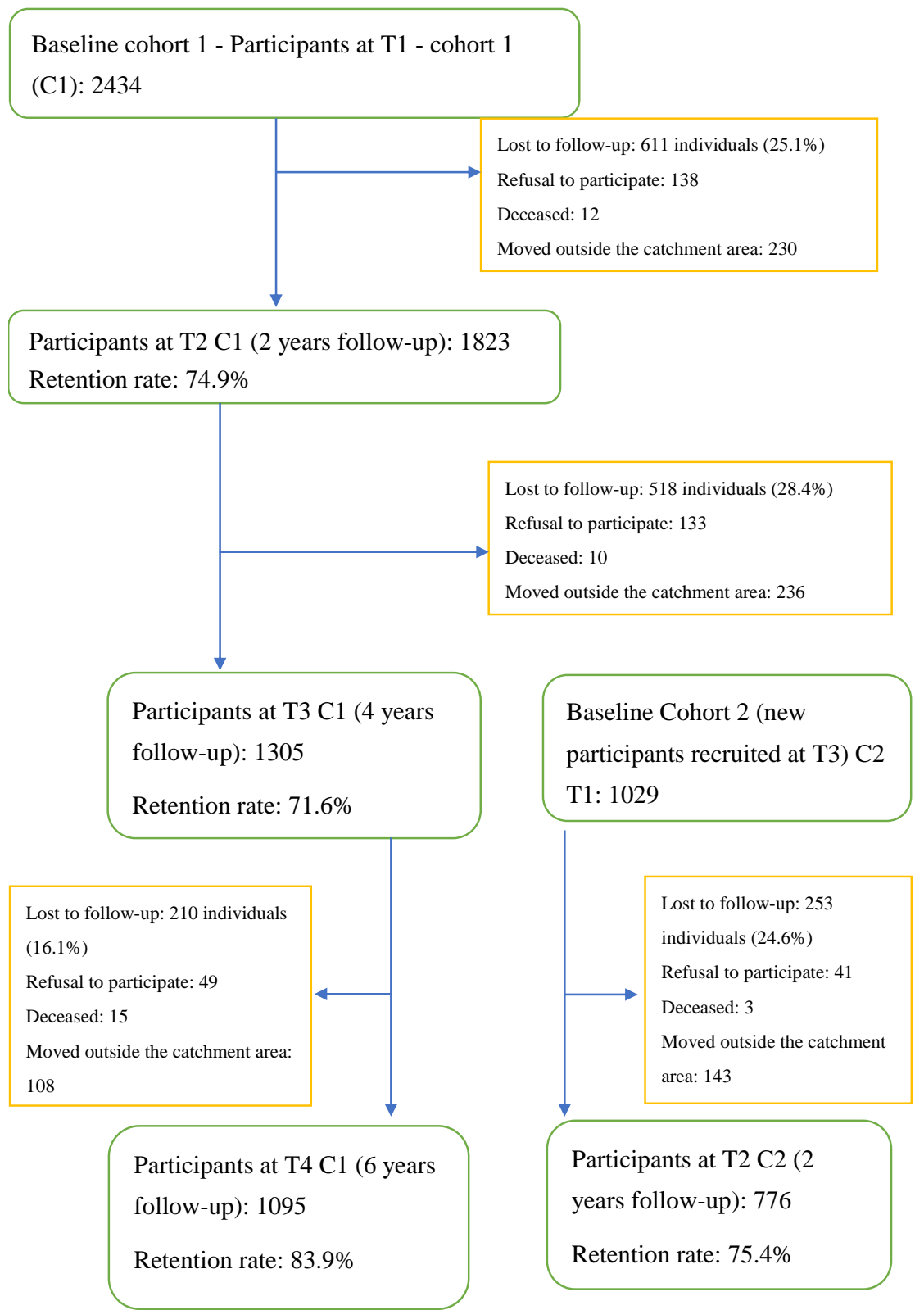

Figure 1. Recruitment flowchart from Time 1 (T1) to T4 data collection periods. Data collection for the present study included: T3 (independent variables) and T4 (dependent variable).

\subsection{Conceptual Framework, Variables, and Instruments}

The dependent variable, "number of types of healthcare professionals consulted for MH reasons", was measured for each participant at T4. Professional consultation was defined as contact with any healthcare professional for $\mathrm{MH}$ reasons in the 12 months prior to the interview: General practitioner, psychiatrist, psychologist, nurse, social worker, etc. Independent variables (measured at T3) were 
integrated based on the literature related to predictors of MH service use $[21,22,38]$ and were classified according to the Andersen model. Predisposing variables included: Age, gender, education, civil status, household size, number of children in the household, and health beliefs such as self-perception of mental health and self-perception of physical health, as well as satisfaction with health services. Enabling variables included: Having a family physician, previous use of MH services (consultations with any healthcare professionals or community service organizations such as self-help groups), and employment status. As MH service use is known to have a strong influence on outcomes such as quality of life, emotional well-being, and personal well-being [21], these variables were also included as enabling factors. Needs factors were categorized as: (a) Clinical needs, i.e., diagnoses (major depressive disorder, generalized anxiety disorder, post-traumatic stress disorder (PTSD), drug and alcohol dependence, as well as high psychological distress, physical illnesses, suicide ideation and (b) other health-related needs, including stressful events, unmet need for help, physical aggression, and functional disability. MH diagnoses with low prevalence such as schizophrenia or personality disorders were not included in the study, as is often the case in population-based studies $[39,40]$. The analytical framework is presented in Figure 2. Table 1 displays the standardized instruments used to measure the variables or dimensions identified above, including sub-dimensions measured and numbers of items, ranges for each score, interpretation of the score, and where possible the Cronbach alpha. These standardized instruments were selected as most of them were used previously in the Canadian Health Survey-Mental health and well-being (CCHS) 1.2 [41], which is however not a longitudinal population study.

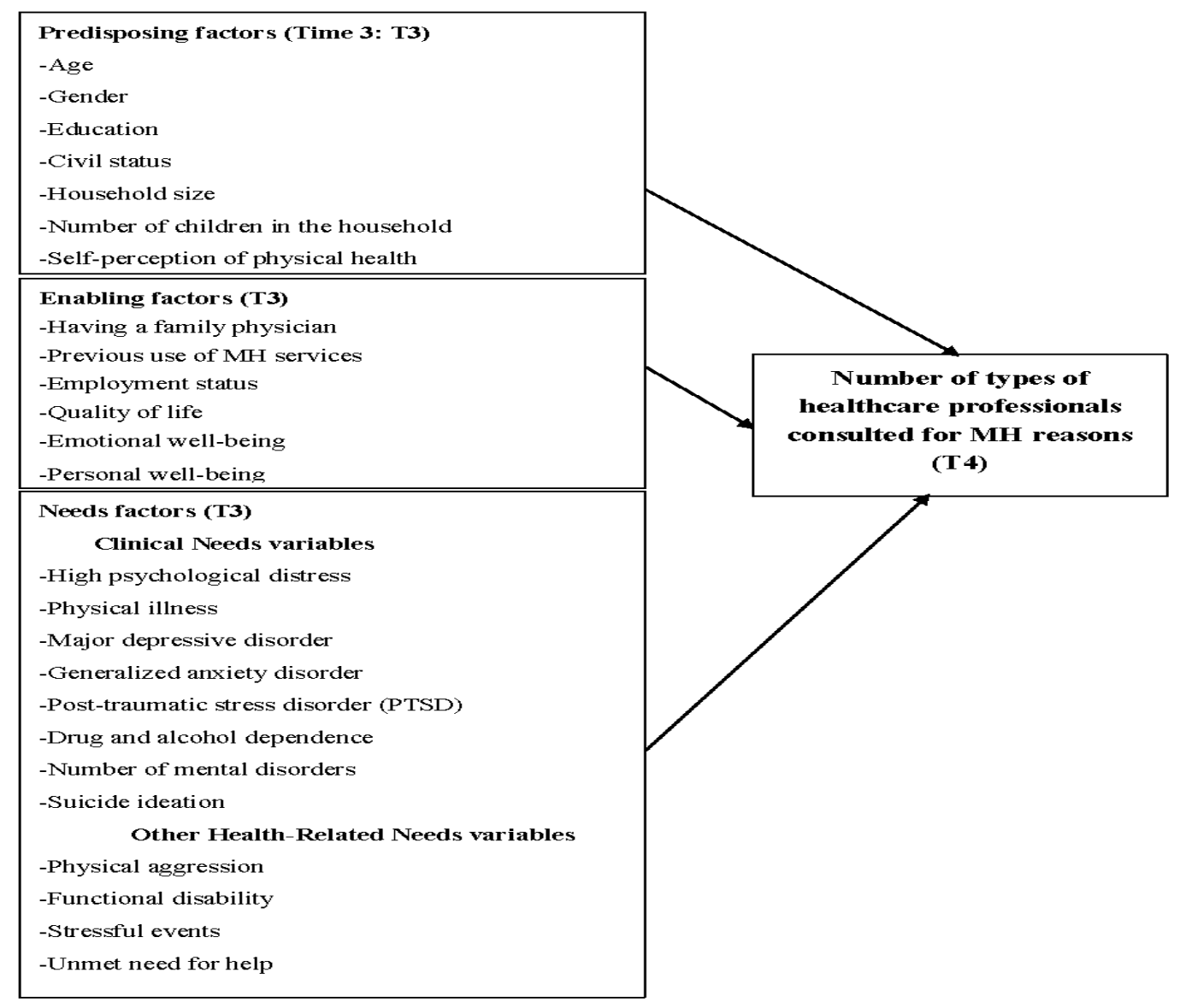

Figure 2. Conceptual framework: ( $N=746$ individuals with mental disorders (MD) or high psychological distress). 
Table 1. Measurement instruments.

\begin{tabular}{|c|c|c|}
\hline Variables & $\begin{array}{l}\text { Instruments, References, and } \\
\text { Psychometric Properties }\end{array}$ & Description \\
\hline \multicolumn{3}{|l|}{ Predisposing factors } \\
\hline Age & $\begin{array}{l}\text { Canadian Community Health Survey of } \\
\text { MH and Well-Being CCHS 1.2 [41] }\end{array}$ & $\begin{array}{c}\text { Calculated from date of birth and confirmed by participants } \\
\text { One item } \\
\text { Numeric value }\end{array}$ \\
\hline Gender & CCHS 1.2 [41] & $\begin{array}{l}\text { As declared by participants } \\
\text { Two items (male/female) }\end{array}$ \\
\hline Civil status & CCHS 1.2 [41] & $\begin{array}{c}\text { As declared by participants } \\
\text { Two items (living as a couple; living alone) }\end{array}$ \\
\hline Household size & CCHS 1.2 [41] & $\begin{array}{l}\text { As declared by participants } \\
\text { One item } \\
\text { Numeric value }\end{array}$ \\
\hline $\begin{array}{l}\text { Number of children in } \\
\text { the household }\end{array}$ & CCHS 1.2 [41] & $\begin{array}{l}\text { As declared by participants } \\
\text { One item } \\
\text { Numeric value }\end{array}$ \\
\hline $\begin{array}{l}\text { Self-perception of } \\
\text { physical health }\end{array}$ & CCHS 1.2 [41] & $\begin{array}{l}\text { Self-perception of physical health } \\
\text { One item } \\
\text { Five-point Likert scale } \\
\text { Higher = more negative }\end{array}$ \\
\hline $\begin{array}{l}\text { Self-perception of mental } \\
\text { health }(\mathrm{MH})\end{array}$ & CCHS 1.2 [41] & $\begin{array}{l}\text { Self-perception of mental health }(\mathrm{MH}) \\
\text { One item } \\
\text { Five-point Likert scale } \\
\text { Higher }=\text { more negative }\end{array}$ \\
\hline $\begin{array}{l}\text { Satisfaction with health } \\
\text { services }\end{array}$ & CCHS 1.2 [41] & $\begin{array}{c}\text { Measure satisfaction with health services } \\
30 \text { items } \\
\text { Four-point Liker scale } \\
\text { Higher }=\text { greater satisfaction }\end{array}$ \\
\hline \multicolumn{3}{|l|}{ Enabling factors } \\
\hline $\begin{array}{l}\text { Having a family } \\
\text { physician }\end{array}$ & CCHS 1.2 [41] & $\begin{array}{c}\text { As declared by participants } \\
\text { Yes/No }\end{array}$ \\
\hline $\begin{array}{l}\text { Previous use of } \mathrm{MH} \\
\text { services }\end{array}$ & CCHS 1.2 [41] & $\begin{array}{l}\text { As declared by participants } \\
\text { Yes/No }\end{array}$ \\
\hline Employment status & CCHS 1.2 [41] & $\begin{array}{l}\text { As declared by participants } \\
\text { Yes/No }\end{array}$ \\
\hline Personal well-being & $\begin{array}{l}\text { Australian Unity Well-being Index [42] } \\
\text { Cronbach alpha: } 0.85\end{array}$ & $\begin{array}{l}\text { Measures personal satisfaction with life as a whole and in Eight } \\
\text { sub-dimensions } \\
\text { Nine items } \\
\text { 10-point Likert scale } \\
\text { Higher = more positive }\end{array}$ \\
\hline Emotional well-being & MH Continuum—Short Form [43] & $\begin{array}{c}\text { Measures the degree of emotional well-being defined in terms of } \\
\text { positive affect/satisfaction with life; social well-being as described in } \\
\text { Keyes [44] model of social well-being } \\
14 \text { items } \\
\text { Seven-point Likert scale } \\
\text { Range: } 1-98 \\
\text { Higher = more negative }\end{array}$ \\
\hline Quality of life & $\begin{array}{l}\text { Satisfaction with Life Domains Scale [45]; } \\
\text { adapted by Baker and Intagliata [46] for } \\
\text { psychiatric patients } \\
\text { Cronbach alpha: } 0.9\end{array}$ & $\begin{array}{l}\text { Quality of life in five domains } \\
\quad 20 \text { items } \\
\text { Seven-point Likert scale } \\
\quad \text { Range: } 0-140 \\
\text { Higher = better quality of life }\end{array}$ \\
\hline \multicolumn{3}{|c|}{ Needs factors } \\
\hline $\begin{array}{l}\text { Major depressive } \\
\text { disorder }\end{array}$ & $\begin{array}{l}\text { Composite International Diagnostic } \\
\text { Interview (CIDI) and CIDI-SF [47] }\end{array}$ & $\begin{array}{l}\text { Psychiatric diagnoses based on the definitions and criteria of ICD-10 } \\
\text { and DSM-IV } \\
\text { ( } \\
\text { Yes/No and multiple choice }\end{array}$ \\
\hline $\begin{array}{l}\text { Generalized anxiety } \\
\text { disorder }\end{array}$ & $\begin{array}{l}\text { Composite International Diagnostic } \\
\text { Interview (CIDI) and CIDI-SF [47] }\end{array}$ & $\begin{array}{c}\text { Psychiatric diagnoses based on the definitions and criteria of ICD-10 } \\
\text { and DSM-IV. } \\
\text { Yes/No and multiple choice }\end{array}$ \\
\hline $\begin{array}{l}\text { Post-traumatic stress } \\
\text { disorder (PTSD) }\end{array}$ & $\begin{array}{l}\text { Composite International Diagnostic } \\
\text { Interview (CIDI) and CIDI-SF [47] }\end{array}$ & $\begin{array}{l}\text { Psychiatric diagnoses based on the definitions and criteria of ICD-10 } \\
\text { and DSM-IV. } \\
\text { Yes/No and multiple choice }\end{array}$ \\
\hline $\begin{array}{l}\text { Drug and alcohol } \\
\text { dependence }\end{array}$ & $\begin{array}{l}\text { Composite International Diagnostic } \\
\text { Interview (CIDI) and CIDI-SF [47] }\end{array}$ & $\begin{array}{c}\text { Psychiatric diagnoses based on the definitions and criteria of ICD-10 } \\
\text { and DSM-IV } \\
\text { Yes/No and multiple choice }\end{array}$ \\
\hline Suicide ideation & Tousignant et al. [48] & $\begin{array}{l}\text { Suicide ideation at life in the last } \\
12 \text { months } \\
\text { Yes/No }\end{array}$ \\
\hline
\end{tabular}


Table 1. Cont.

\begin{tabular}{|c|c|c|}
\hline Variables & $\begin{array}{l}\text { Instruments, References, and } \\
\text { Psychometric Properties }\end{array}$ & Description \\
\hline Functional disability & $\begin{array}{l}\text { 12-item version of the World Health } \\
\text { Organization Disability Assessment } \\
\text { Schedule II (WHO-DAS-II) [49] }\end{array}$ & $\begin{array}{c}\text { Measure functional disability } \\
12 \text { items } \\
\text { Five-point Likert-scale } \\
\text { Range: } 0-60 \\
\text { Score of } 45 \text { or greater indicates substantial disability [50] }\end{array}$ \\
\hline Stressful events & Lifetime Events Questionnaire [51] & $\begin{array}{l}\text { Stressful events in the last } 12 \text { months related to housing, family and } \\
\text { friends, income, love, and } \\
\text { aggressive experiences } \\
25 \text { items } \\
\text { Yes/No }\end{array}$ \\
\hline $\begin{array}{l}\text { High psychological } \\
\text { distress }\end{array}$ & $\begin{array}{c}\text { K-10 scale [52] } \\
\text { Cronbach alpha: } 0.93\end{array}$ & $\begin{array}{c}\text { Measure frequency of distress symptoms in the past month such as } \\
\text { nervousness, tiredness, despair, agitation, sadness, and feeling of } \\
\text { worthlessness } \\
10 \text { items } \\
\text { Five-point Likert scale } \\
\text { (cut-off point for determining high psychological distress =9) }\end{array}$ \\
\hline Physical illnesses & CCHS 1.2 [41] & $\begin{array}{c}\text { Number of physical illness as declared by participants } \\
\text { Yes/No }\end{array}$ \\
\hline Physical aggression & Modified Observed Aggression Scale [53] & $\begin{array}{c}\text { Assess } 4 \text { categories of aggressive behavior: Verbal aggression, } \\
\text { aggression to propriety, self-inflicted aggression, physical aggression } \\
20 \text { items } \\
\text { Yes/No }\end{array}$ \\
\hline Unmet need for help & $\begin{array}{l}\text { Perceived Need for Care Questionnaire } \\
\text { [54] }\end{array}$ & $\begin{array}{l}\text { Five items } \\
\text { Yes/No }\end{array}$ \\
\hline
\end{tabular}

${ }^{\mathrm{a}}$ ICD: International classification of diseases; ${ }^{\mathrm{b}}$ DSM: Diagnostic and Statistical Manual of Mental Disorders.

\subsection{Analyses}

Univariate, bivariate, and multivariate analyses were performed. Missing values were also treated by imputation technics (however, fewer than $5 \%$ of variables had missing values). Univariate analyses consisted of frequency distributions for categorical variables and central tendency measures (mean values and standard deviations) for continuous variables. A bivariate linear regression analysis was conducted for each independent variable to determine which ones were associated with a higher number of different types of healthcare professionals consulted for MH reasons. Significant independent variables in the bivariate analyses $(p<0.10)$ were used to build the hierarchical linear regression model, with the alpha value set at $p<0.05$ to determine which factors in the model were significant. Following the study hypothesis, clinical needs variables were entered into the model first, followed by other needs variables, then predisposing and enabling factors. Needs factors were divided into "clinical" needs factors (e.g., diagnoses) and "other" needs factors (e.g., functional disability) to highlight the differences between them in terms of impact on service utilization. For each block of variables, the goodness-of-fit was determined with the Hosmer-Lemeshow test and the variance explained using the Nagelkerke $R^{2}$.

\section{Results and Discussion}

\subsection{Results}

Out of the large epidemiological catchment study, 1871 participants were selected from T4 for the present study. Within this group, 746 had either a diagnosed MD $(\mathrm{N}=201 ; 27 \%)$ or high psychological distress $(\mathrm{N}=713 ; 96 \%)$. Table 2 shows the main characteristics of those participants at $\mathrm{T} 3$, as well as bivariate associations with the number of healthcare professionals visited at $\mathrm{T} 4$. Regarding predisposing factors, mean age was 44 years (Table 2). Participants consisted of nearly twice as many women as men $(62 \%$ vs. $38 \%)$. Most lived alone (63\%). Their self-perception of physical health (2.8 on 5; SD: 1.1$)$ and of MH (2.9 on 5; SD: 1.0) were average, as well as their satisfaction with MH services (51.7 on 100; SD: 13.8). Regarding enabling factors, over two thirds (69\%) had a family physician. Over the previous 12 months, $29 \%(\mathrm{~N}=219)$ had visited a healthcare professional for $\mathrm{MH}$ reasons. Of the total sample, participants most frequently consulted general practitioners $(15 \%, \mathrm{~N}=112)$, followed 
by psychologists at $14 \%(\mathrm{~N}=104)$ and psychiatrists at $8 \%(\mathrm{~N}=60)$. Sixty-two percent of those who visited a healthcare professional $(\mathrm{N}=136 / 219)$ consulted a single healthcare professional, usually a general practitioner $(25 \%, \mathrm{~N}=34 / 136)$; while $26 \%(\mathrm{~N}=56 / 219)$ consulted two healthcare professionals, usually a general practitioner and a psychologist $(57 \%, \mathrm{~N}=32 / 56)$, and $11 \%(\mathrm{~N}=25 / 217)$ at least three healthcare professionals, usually a general practitioner, psychologist, and psychiatrist. Only $19 \%$ had held a job during the previous year. Regarding needs factors, major depression was most prevalent $(17 \%)$, and $9 \%$ experienced suicide ideation. The psychological distress score was relatively high (13.8; SD: 5.3). The mean number of stressful events per participant was 3.8 (SD: 2.4). Physical illnesses were also prevalent among participants $(64 \%)$. Independent variables significantly associated with the dependent variable, number of types of healthcare professionals consulted for $\mathrm{MH}$ reasons, in the bivariate analyses (Table 2) were used to build the hierarchical linear regression model.

Table 2. Participant characteristics and bivariate associations with number of types of healthcare professionals consulted for mental health $(\mathrm{MH})$ reasons $(\mathrm{N}=746)$.

\begin{tabular}{|c|c|c|c|c|c|c|c|c|}
\hline & \multirow[b]{2}{*}{ Variables at T3 } & \multicolumn{4}{|c|}{ Frequency Distributions } & \multicolumn{3}{|c|}{$\begin{array}{l}\text { Bivariate Associations with } \\
\text { Number of Healthcare } \\
\text { Professionals Visited at T4 }\end{array}$} \\
\hline & & Min & Max & n/Mean & $\% / S D$ & Beta & $t$ & $p$ Value \\
\hline \multirow{9}{*}{$\begin{array}{l}\text { Predisposing } \\
\text { factors }\end{array}$} & Age & 15.00 & 72.00 & 43.71 & 14.04 & 0.011 & 0.289 & 0.773 \\
\hline & & & & 460 & 61.7 & 1 & & \\
\hline & Male & & & 286 & 38.3 & -0.063 & -1.725 & 0.085 \\
\hline & \multirow{2}{*}{ Civil status } & & & 473 & 63.4 & 1 & & \\
\hline & & & & 273 & 36.6 & -0.106 & -2.903 & 0.004 \\
\hline & \multirow{4}{*}{$\begin{array}{c}\text { Household size } \\
\text { Self-perception of physical health in the } \\
\text { past } 12 \text { months } \\
\text { Self-perception of } \mathrm{MH} \\
\text { Satisfaction with health services }\end{array}$} & 0.00 & 13.00 & 2.47 & 1.47 & -0.071 & -1.950 & 0.052 \\
\hline & & 1.00 & 5.00 & 2.75 & 1.05 & -0.128 & -3.529 & $<0.001$ \\
\hline & & 1.00 & 5.00 & 2.89 & 0.98 & -0.287 & -8.179 & $<0.001$ \\
\hline & & 4.00 & 90.00 & 51.68 & 13.78 & -0.136 & -3.747 & $<0.001$ \\
\hline \multirow{7}{*}{$\begin{array}{l}\text { Enabling } \\
\text { factors }\end{array}$} & \multirow{4}{*}{$\begin{array}{l}\text { Having a family physician } \\
\text { Previous use of services for MH reasons } \\
\text { Private insurance coverage including } \\
\text { visits to psychologist } \\
\text { Employment status }\end{array}$} & & & 515 & 69.0 & 0.130 & 3.568 & $<0.001$ \\
\hline & & & & 219 & 29.4 & 0.346 & 10.065 & $<0.001$ \\
\hline & & & & 46 & 6.2 & 0.142 & 3.921 & $<0.001$ \\
\hline & & & & 138 & 18.5 & 0.098 & 2.685 & 0.007 \\
\hline & Quality of life (QOL) (total score) $^{\mathrm{a}}$ & 45.00 & 135.00 & 100.95 & 15.50 & -0.199 & -5.533 & $<0.001$ \\
\hline & Emotional well-being $\mathrm{b}$ & 4.00 & 70.00 & 42.47 & 12.20 & -0.159 & -4.404 & $<0.001$ \\
\hline & Personal well-being ${ }^{\mathrm{C}}$ & 2.00 & 90.00 & 58.48 & 13.69 & -0.186 & -5.168 & $<0.001$ \\
\hline \multirow{12}{*}{ Needs factors } & Stressful events (total score) & 0.00 & 14.00 & 3.84 & 2.45 & 0.221 & 6.174 & $<0.001$ \\
\hline & High psychological distress & 0.00 & 35.00 & 13.83 & 5.13 & 0.201 & 5.593 & $<0.001$ \\
\hline & Physical illnesses & & & 1.36 & 1.47 & 0.079 & 2.169 & 0.030 \\
\hline & Unmet need for help & & & 110 & 14.7 & 0.151 & 4.171 & $<0.001$ \\
\hline & Major depressive episode & & & 129 & 17.3 & 0.250 & 7.028 & $<0.001$ \\
\hline & Generalized anxiety disorder & & & 15 & 2.0 & 0.099 & 2.707 & 0.007 \\
\hline & Post-traumatic stress disorder (PTSD) & & & 50 & 6.7 & 0.225 & 6.286 & $<0.001$ \\
\hline & Drug and alcohol dependence & \multirow{3}{*}{0.00} & \multirow{3}{*}{5.00} & 29 & 3.9 & 0.070 & 1.916 & 0.056 \\
\hline & Number of mental disorders & & & 0.37 & 0.71 & 0.253 & 7.142 & $<0.001$ \\
\hline & Physical aggression & & & 43 & 5.8 & 0.085 & 2.332 & 0.020 \\
\hline & Functional disability ${ }^{\mathrm{d}}$ & 13.00 & 49.00 & 19.33 & 6.91 & 0.186 & 5.157 & $<0.001$ \\
\hline & Suicide ideation & & & 69 & 9.2 & 0.213 & 5.949 & $<0.001$ \\
\hline
\end{tabular}

a Rating: 20-140; higher = better quality of life. ${ }^{b}$ Rating: 1-98; higher = more negative emotional well-being.

c Rating: 0-90; higher = greater personal well-being. ${ }^{\mathrm{d}}$ Rating: 0-60; higher $=$ higher disability.

The hierarchical linear regression model is presented in Table 3 and includes four blocks: Clinical needs, other health-related needs (needs factors), predisposing, and enabling factors. The first factor, clinical needs, yielded five positively associated variables: Psychological distress, major depressive disorder, generalized anxiety disorder, PTSD, and suicide ideation. These variables remained significantly associated with the dependent variable after the introduction of the second block, other health-related needs factors, with the exception of psychological distress, and two new variables were added: Stressful events and functional disability, which were both positively associated with the dependent variable. After introduction of the third block, predisposing factors, one variable, self-perception of $\mathrm{MH}$, was negatively associated with the dependent variable, meaning that those who perceived their $\mathrm{MH}$ as excellent were less likely to visit a greater variety of healthcare professionals for 
MH reasons. Regarding the fourth block, enabling factors, three variables, previous use of services for $\mathrm{MH}$ reasons, having a family physician, and employment status were positively associated with the dependent variable, in addition to the four previously entered variables: PTSD, stressful events, self-perception of $\mathrm{MH}$, and (marginally) suicide ideation. The total variance explained by the four model was $21 \%: 11 \%$ for clinical needs and $2 \%$ for other health-related needs, $2 \%$ for predisposing factors, and $6 \%$ for enabling factors, respectively to the final model. The goodness-of-fit was acceptable.

\subsection{Discussion}

Based on this catchment area study, slightly less than one-third of the sample reported consulting healthcare professionals for $\mathrm{MH}$ reasons in the previous year. This result falls within the low range of consultations (from $5 \%$ in low income to $44 \%$ in high income countries) observed in previous population studies $[22,55,56]$, which may be explained by the inclusion of individuals with high psychological distress in our sample of diagnosed individuals with MD. Among those who consulted a single healthcare professional, general practitioners and psychologists were equally favored, followed by psychiatrists. This order in the choice of healthcare professionals is consistent with previous Quebec epidemiological studies [24,57]. The finding that fewer than four in ten individuals had used at least two healthcare professionals makes sense, as psychotherapy and treatment with medication are generally recommended in combination with the management of $\mathrm{MH}$ conditions in step-care models $[16,58]$. The finding that a minority (about 10\%) required consultations with psychiatrists corresponded to the rate of more complex, recurrent, or serious MD in the sample [59]. It is well known that general practitioners have difficulty treating such complex cases in primary care settings [60].

The hierarchical regression model revealed that needs factors predicted the highest number of types of healthcare professionals consulted for $\mathrm{MH}$ reasons, followed by enabling factors; whereas the contribution of predisposing factors was marginal. These findings confirm our hypothesis that individuals with complex or serious needs would be more inclined to consult a greater number of different types of healthcare professionals. However, it should be noted that there were equivalent numbers of significant needs factors (PTSD, stressful events, and (marginally) suicide ideation) and enabling factors (previous use of $\mathrm{MH}$ services, having a family physician, and employment status) in the final model; whereas only one predisposing factor (self-perception of $\mathrm{MH}$ ) remained significant. Interestingly, three needs factors (major depressive disorder, generalized anxiety disorder, and functional disability) ceased to be associated with the dependent variable after the block of enabling factors was introduced into the model, suggesting that the presence of enabling factors substantially reduced the influence of these needs factors on number of different types of healthcare professionals consulted for $\mathrm{MH}$ reasons.

As predicted in this study, and reported previously [24,61], we found that the presence of a diagnosed MD was associated with the likelihood of consulting a greater number of healthcare professionals. Specifically, two clinical needs variables (PTSD and (marginally) suicide ideation) were associated with the dependent variable in the final model. A Canadian study found that individuals with PTSD usually experience chronic symptoms causing functional impairment and high rates of comorbidity [62]. Another study found an association between PTSD and substantial reduction in quality of life affecting general health, energy levels, emotional and physical well-being, as well as social functioning [63]. Reports indicate that individuals with suicide ideation are also more likely to seek treatment from both a general practitioner and $\mathrm{MH}$ specialist [64]. This may reflect a perceived need for $\mathrm{MH}$ care on the part of individuals with suicidal thoughts and behaviors [65]. Among individuals with suicide ideation, perceived need for $\mathrm{MH}$ care has been associated with increased likelihood of service use [65]. A study on MH care for adults with suicide ideation [66] found that perceived need for care predicted nearly four times the likelihood of receiving treatment. 'Stressful life events' was the only other health-related needs variable associated with the number of types of healthcare professionals consulted for $\mathrm{MH}$ reasons. There is considerable evidence that individuals who have experienced an above average number of negative life events are more likely to experience 
psychological distress [67]; they also have greater odds of developing PTSD [68] or other MD [69-71] and are more likely to seek MH services [68,72].

Three enabling factors predicted consultations with a greater number of different types of healthcare professionals for MH reasons: Previous use of MH services, employment status, and having a family physician. Due to the chronic nature of certain MH conditions, episodes of relapse or recurrence [4] may require adherence to treatment over a longer period for achieving better outcomes. Past research has also found that prior treatment history for MD was associated with more positive attitudes toward medical interventions [73] and help-seeking from various providers [74]. Knowledge and experience with services are recognized as facilitators in accessing care [75]. Having a family physician also provides an entry point to the healthcare system: Family physicians diagnose and treat patients who present with $\mathrm{MH}$ symptoms, making referrals of more severe or complex cases to specialized MH professionals [76,77]. By contrast, not having a family physician may result in unmet needs for care [78] or delayed access to $\mathrm{MH}$ care, especially among individuals unaware of their $\mathrm{MH}$ symptoms and the available resources [75]. This finding underscores the importance of integrating MH into primary care, improving continuity of care by making family physicians universally available, and increasing their training in the screening and treatment of $\mathrm{MH}$ problems, and better supporting them through collaborative care models. Employment status was another predictor of the number of different types of healthcare professionals consulted for MH reasons. Quite possibly, employed individuals have greater access to certain healthcare professionals, including private psychologists [5]. Moreover, employee assistance programs may offer workplace educational support, counseling, confidential screening, and assessment [79]. While unemployed individuals may feel depressed or have a greater need for MH care [80], those who occupy positions with high levels of job insecurity or negative stress may be at even higher risk of MH problems. For instance, one study [81] reported that employed individuals with perceived job insecurity were more likely to have poor MH status and greater need for care than unemployed individuals; they also made greater use of MH services [81].

Finally, one predisposing factor, self-perception of $\mathrm{MH}$, negatively predicted the number of different types of healthcare professionals consulted for $\mathrm{MH}$ reasons. This corresponds to previous findings suggesting that patients who had a worse self-perception of their $\mathrm{MH}$ were more likely to seek help from general practitioners and $\mathrm{MH}$ specialists rather than relying on a single healthcare professional [82,83]. Another study [24] found that individuals who rated their MH worse were more likely to seek help from either a general practitioner and psychologist, or a general practitioner and psychiatrist. This finding underscores the relevance of individual perceptions on the need for care in the absence of a MD and MH service utilization. 
Table 3. Predictors of number of types of healthcare professionals consulted for mental health (MH) reasons ( $\mathrm{N}=746)$ : Multiple linear regression model.

\begin{tabular}{|c|c|c|c|c|c|c|c|c|c|c|c|c|c|c|}
\hline & \multirow{3}{*}{ Variables } & \multicolumn{2}{|c|}{ Block 1} & \multicolumn{2}{|c|}{ Block 2} & \multicolumn{2}{|c|}{ Block 3} & \multicolumn{7}{|c|}{ Block 4} \\
\hline & & \multirow{2}{*}{ Beta } & \multirow{2}{*}{$p$} & \multirow{2}{*}{ Beta } & \multirow{2}{*}{$p$} & \multirow{2}{*}{ Beta } & \multirow{2}{*}{$p$} & \multirow{2}{*}{ Beta } & \multirow{2}{*}{$t$} & \multirow{2}{*}{$p$} & \multicolumn{2}{|c|}{$95.0 \%$ CI for B } & \multicolumn{2}{|c|}{$\begin{array}{l}\text { Collinearity } \\
\text { Statistics }\end{array}$} \\
\hline & & & & & & & & & & & $\mathbf{L B}^{\mathbf{a}}$ & UB $^{b}$ & Tolerance & VIF $^{c}$ \\
\hline \multirow{6}{*}{$\begin{array}{l}\text { Needs } 1 \text { Factors } \\
\text { (Clinical) }\end{array}$} & (Constant) & & 0.128 & & 0.278 & & 0.012 & & 0.761 & 0.447 & -0.205 & 0.464 & & \\
\hline & High psychological distress & 0.085 & 0.024 & 0.042 & 0.286 & -0.004 & 0.926 & 0.003 & 0.081 & 0.935 & -0.012 & 0.013 & 0.676 & 1.480 \\
\hline & Major depressive disorder & 0.159 & $<0.001$ & 0.132 & $<0.001$ & 0.102 & 0.007 & 0.055 & 1.476 & 0.140 & -0.039 & 0.274 & 0.771 & 1.297 \\
\hline & Generalized anxiety disorder (GAD) & 0.085 & 0.014 & 0.078 & 0.023 & 0.071 & 0.038 & 0.050 & 1.520 & 0.129 & -0.084 & 0.662 & 0.981 & 1.020 \\
\hline & Post-traumatic stress disorder (PTSD) & 0.146 & $<0.001$ & 0.123 & 0.001 & 0.124 & 0.001 & 0.105 & 2.945 & 0.003 & 0.113 & 0.566 & 0.838 & 1.193 \\
\hline & Suicide ideation & 0.114 & 0.002 & 0.101 & 0.005 & 0.085 & 0.017 & 0.062 & 1.776 & 0.076 & -0.018 & 0.364 & 0.879 & 1.138 \\
\hline \multirow{2}{*}{$\begin{array}{l}\text { Needs } 2 \text { Factors } \\
\text { (Other-Clinical) }\end{array}$} & Stressful events & & & 0.126 & $<0.001$ & 0.098 & 0.007 & 0.098 & 2.746 & 0.006 & 0.009 & 0.056 & 0.830 & 1.205 \\
\hline & Functional disability & & & 0.085 & 0.028 & 0.080 & 0.036 & 0.050 & 1.355 & 0.176 & -0.003 & 0.014 & 0.778 & 1.285 \\
\hline Predisposing & Self-perception of MH & & & & & -0.157 & $<0.001$ & -0.116 & -2.983 & 0.003 & -0.159 & -0.033 & 0.705 & 1.419 \\
\hline \multirow{3}{*}{ Enabling Factors } & Previous use of MH services & & & & & & & 0.217 & 5.930 & $<0.001$ & 0.258 & 0.513 & 0.797 & 1.255 \\
\hline & Having a family physician & & & & & & & 0.112 & 3.358 & 0.001 & 0.082 & 0.311 & 0.954 & 1.048 \\
\hline & Employment status & & & & & & & 0.079 & 2.332 & 0.020 & 0.026 & 0.301 & 0.940 & 1.064 \\
\hline \multirow{2}{*}{ Goodness of fit } & $\mathrm{F}$ & \multirow{2}{*}{\multicolumn{2}{|c|}{$\begin{array}{l}20.038 \\
<0.001\end{array}$}} & \multirow{2}{*}{\multicolumn{2}{|c|}{$\begin{array}{l}17.340 \\
<0.001\end{array}$}} & \multirow{2}{*}{\multicolumn{2}{|c|}{$\begin{array}{l}17.450 \\
<0.001\end{array}$}} & \multirow{2}{*}{\multicolumn{7}{|c|}{$\begin{array}{l}18.543 \\
<0.001\end{array}$}} \\
\hline & $p$ & & & & & & & & & & & & & \\
\hline \multicolumn{2}{|c|}{ Total variance explained (Adjusted R Square) } & \multicolumn{2}{|c|}{0.113} & \multicolumn{2}{|c|}{0.133} & \multicolumn{2}{|c|}{0.150} & \multicolumn{7}{|c|}{0.206} \\
\hline
\end{tabular}

${ }^{\text {a }}$ LB: Lower Bound; ${ }^{\mathrm{b}}$ UB: Upper Bound; ${ }^{\mathrm{c}}$ VIF: Variable inflation factor. 


\subsection{Limitations}

The findings of this study should be considered in light of certain limitations. First, the frequency of consultations with each healthcare professional was not taken into account. As such, continuity and appropriateness of care were not considered, which are key dimensions impacting quality of care and patient recovery. Second, the diversity of types of healthcare professionals consulted did not take into account the existence of actual collaboration among them, as required in collaborative care models. Third, some pertinent predictors of consultations with different types of healthcare professionals for MH reasons that may influence service utilization, including lifetime disorders, symptoms severity, suicide attempt [27], ethnicity, or religion [84] were not measured in this study. Fourth, populations younger than 15 and older than 65 were excluded from the study, as MH health service use patterns for these age groups are very distinct. Fifth, the study did not cover the full spectrum of MD, as some disorders assessed in the third data collection period were not assessed in the fourth data collection. Serious MD with very low population prevalence, such as schizophrenia and personality disorders, were also excluded. Six, the final study sample (at T4) was less representative of the population (i.e., in terms of youth, individuals with high material deprivation, and substance use disorders). Finally, the total variance $(21 \%)$ explained by our model was relatively low.

\section{Conclusions}

This study was innovative in assessing predictors of diversity in the number of types of healthcare professional consultations for MH reasons among individuals, not only those diagnosed with MD, but mainly those affected by high psychological distress, using the Andersen Behavioral Model. This latter clientele is often overlooked by MH professionals, who focus mainly on diagnosed MD cases in their practices. Findings revealed that needs factors were most strongly associated with the number of types of healthcare professionals consulted, but that enabling factors may reduce the influence of certain needs factors, particularly those involving clinical variables. Multiple variables associated with consultations of a greater number of different types of healthcare professionals for $\mathrm{MH}$ reasons were identified: PTSD, stressful events, previous use of MH services, employment status, having a family physician, self-perception of $\mathrm{MH}$, and (marginally) suicide ideation. The identification of specific predictors may help orient $\mathrm{MH}$ programs and interventions. Considering that enabling factors are easier to tackle than needs or predisposing factors, it would be important for $\mathrm{MH}$ managers to prioritize the development of collaborative care models to facilitate continuity and appropriateness of services for individuals who view their $\mathrm{MH}$ as poor. Moreover, all individuals with $\mathrm{MH}$ problems should have a family physician to provide an entry point to the healthcare system. Family physicians are responsible for addressing a wide range of $\mathrm{MH}$ needs, but also for making referrals to specialized $\mathrm{MH}$ services in more severe or complex cases, such as PTSD. Further extensions of employment assistance programs may facilitate better $\mathrm{MH}$, as such support in the workplace may serve as an antidote to stress and related $\mathrm{MH}$ problems, while providing individuals with the means to consult $\mathrm{MH}$ specialists when needed. Finally, information on help-line services and crisis centers should be more widely disseminated, given the numbers of individuals affected by stressful events and suicide ideation.

Author Contributions: Project administration and resources: J.C.; article conceptualization and methodology: B.S., J.-M.B., and M.-J.F.; analysis: J.-M.B.; original draft preparation: B.S., G.G., and M.-J.F.; review and editing: M.-J.F. and J.C.; supervision: M.-J.F.

Funding: The study was funded by the Canadian Institutes of Health Research (CTP-79839).

Acknowledgments: We gratefully acknowledge the support of the Canadian Institutes of Health Research (CIHR), as well as our partners and those who participated in this study.

Conflicts of Interest: The authors declare no conflict of interest. 


\section{References}

1. Prince, M.; Patel, V.; Saxena, S.; Maj, M.; Maselko, J.; Phillips, M.R.; Rahman, A. No health without mental health. Lancet 2007, 370, 859-877. [CrossRef]

2. Whiteford, H.A.; Degenhardt, L.; Rehm, J.; Baxter, A.J.; Ferrari, A.J.; Erskine, H.E.; Charlson, F.J.; Norman, R.E.; Flaxman, A.D.; Johns, N.; et al. Global burden of disease attributable to mental and substance use disorders: Findings from the Global Burden of Disease Study 2010. Lancet 2013, 382, 1575-1586. [CrossRef]

3. Andrews, G.; Slade, T.; Issakidis, C. Deconstructing current comorbidity: Data from the Australian National Survey of Mental Health and Well-Being. Br. J. Psychiatry 2002, 181, 306-314. [CrossRef]

4. Patten, S.B. Recurrence risk in major depression. Depress Anxiety 2013, 30, 1-4. [CrossRef] [PubMed]

5. Fleury, M.-J.; Grenier, G.; Bamvita, J.-M.; Perreault, M.; Caron, J. Determinants of the Utilization of Diversified Types of Professionals for Mental Health Reasons in a Montreal (Canadian) Catchment Area. Glob. J. Heal. Sci. 2012, 4, 13-29. [CrossRef]

6. Wang, P.S.; Aguilar-Gaxiola, S.; Alonso, J.; Angermeyer, M.C.; Borges, G.; Bromet, E.J.; Bruffaerts, R.; de Girolamo, G.; de Graaf, R.; Gureje, O.; et al. Use of mental health services for anxiety, mood, and substance disorders in 17 countries in the WHO world mental health surveys. Lancet 2007, 370, 841-850. [CrossRef]

7. Kessler, R.C.; Demler, O.; Frank, R.G.; Olfson, M.; Pincus, H.A.; Walters, E.E.; Wang, P.S.; Wells, K.B.; Zaslavsky, A.M. Prevalence and treatment of mental disorders, 1990 to 2003. N. Engl. J. Med. 2005, 352, 2515-2523. [CrossRef] [PubMed]

8. Wang, J.; Patten, S.B. Perceived Effectiveness of mental health care provided by primary-car physicians and mental health specialists. Psychosomatics 2007, 48, 123-127. [CrossRef] [PubMed]

9. Archer, J.; Bower, P.; Gilbody, S.; Lovell, K.; Richards, D.; Gask, L.; Dickens, C.; Coventry, P. Collaborative care for depression and anxiety problems. Cochrane Database Syst. Rev. 2012, 10, CD006525. [CrossRef]

10. Bedell, J.R.; Cohen, N.L.; Sullivan, A. Case Management: The Current Best Practices and the Next Generation of Innovation. Community Ment. Heal. J. 2000, 36, 179-194. [CrossRef]

11. Carter, J.J.; Zawalski, S.; Sminkey, P.V.; Christopherson, B. Assessing the whole person: Case managers take a holistic approach to physical and mental health. Prof. Case Manag. 2015, 20, 140-146. [CrossRef] [PubMed]

12. Ivbijaro, G.O.; Enum, Y.; Khan, A.A.; Lam, S.S.-K.; Gabzdyl, A. Collaborative Care: Models for Treatment of Patients with Complex Medical-Psychiatric Conditions. Curr. Psychiatry Rep. 2014, 16, 506. [CrossRef] [PubMed]

13. Kisely, S.; Duerden, D.; Shaddick, S.; Jayabarathan, A. Collaboration between primary care and psychiatric services: Does it help family physicians? Can. Fam. Physician 2006, 52, 876-877. [PubMed]

14. Katon, W.J.; Lin, E.H.; Von Korff, M.; Ciechanowski, P.; Ludman, E.J.; Young, B.; Peterson, D.; Rutter, C.M.; McGregor, M.; McCulloch, D. Collaborative Care for Patients with Depression and Chronic Illnesses. N. Engl. J. Med. 2010, 363, 2611-2620. [CrossRef] [PubMed]

15. Woltmann, E.; Grogan-Kaylor, A.; Perron, B.; Georges, H.; Kilbourne, A.M.; Bauer, M.S. Comparative Effectiveness of Collaborative Chronic Care Models for Mental Health Conditions Across Primary, Specialty, and Behavioral Health Care Settings: Systematic Review and Meta-Analysis. Am. J. Psychiatry 2012, 169, 790-804. [CrossRef] [PubMed]

16. Huffman, J.C.; Niazi, S.K.; Rundell, J.R.; Sharpe, M.; Katon, W.J. Essential Articles on Collaborative Care Models for the Treatment of Psychiatric Disorders in Medical Settings: A Publication by the Academy of Psychosomatic Medicine Research and Evidence-Based Practice Committee. Psychosomatics 2014, 55, $109-122$. [CrossRef] [PubMed]

17. LeDoux, Y.; Minner, P. Occasional and frequent repeaters in a psychiatric emergency room. Soc. Psychiatry Psychiatr. Epidemiol. 2006, 41, 115-121. [CrossRef]

18. Pasic, J.; Russo, J.; Roy-Byrne, P. High Utilizers of Psychiatric Emergency Services. Psychiatr. Serv. 2005, 56, 678-684. [CrossRef]

19. Chaput, Y.J.A.; Lebel, M.-J. Demographic and Clinical Profiles of Patients Who Make Multiple Visits to Psychiatric Emergency Services. Psychiatr. Serv. 2007, 58, 335-341. [CrossRef]

20. Wang, P.S.; Demler, O.; Olfson, M.; Pincus, H.A.; Wells, K.B.; Kessler, R.C. Changing Profiles of Service Sectors Used for Mental Health Care in the United States. Am. J. Psychiatry 2006, 163, 1187-1198. [CrossRef] [PubMed] 
21. Andersen, R.M. Revisiting the Behavioral Model and Access to Medical Care: Does it Matter? J. Heal. Soc. Behav. 1995, 36, 1. [CrossRef]

22. Roberts, T.; Esponda, G.M.; Krupchanka, D.; Shidhaye, R.; Patel, V.; Rathod, S. Factors associated with health service utilisation for common mental disorders: A systematic review. BMC Psychiatry 2018, 18, 262. [CrossRef] [PubMed]

23. Wang, J. Perceived Barriers to Mental Health Service Use among Individuals with Mental Disorders in the Canadian General Population. Med. Care 2006, 44, 192-195. [CrossRef] [PubMed]

24. Vasiliadis, H.-M.; Tempier, R.; Lesage, A.; Kates, N. General practice and mental health care: Determinants of outpatient service use. Can. J. Psychiatry 2009, 54, 468-476. [CrossRef]

25. Fleury, M.-J.; Ngui, A.N.; Bamvita, J.-M.; Grenier, G.; Caron, J. Predictors of Healthcare Service Utilization for Mental Health Reasons. Int. J. Environ. Res. Public Heal. 2014, 11, 10559-10586. [CrossRef]

26. Fleury, M.-J.; Grenier, G.; Bamvita, J.-M.; Perreault, M.; Caron, J. Variables Associated with Perceived Unmet Need for Mental Health Care in a Canadian Epidemiologic Catchment Area. Psychiatr. Serv. 2016, 67, 78-85. [CrossRef]

27. Bobevski, I.; Rosen, A.; Meadows, G. Mental health service use and need for care of Australians without diagnoses of mental disorders: Findings from a large epidemiological survey. Epidemiol. Psychiatr. Sci. 2017, 26, 596-606. [CrossRef] [PubMed]

28. Burgess, P.M.; Pirkis, J.E.; Slade, T.N.; Johnston, A.K.; Meadows, G.N.; Gunn, J.M. Service Use for Mental Health Problems: Findings from the 2007 National Survey of Mental Health and Wellbeing. Aust. N. Z. J. Psychiatry 2009, 43, 615-623. [CrossRef]

29. Haller, H.; Cramer, H.; Lauche, R.; Gass, F.; Dobos, G.J. The prevalence and burden of subthreshold generalized anxiety disorder: A systematic review. BMC Psychiatry 2014, 14, 128. [CrossRef] [PubMed]

30. Cuijpers, P.; Smit, F.; Willemse, G. Predicting the onset of major depression in subjects with subthreshold depression in primary care: A prospective study. Acta Psychiatr. Scand. 2005, 111, 133-138. [CrossRef]

31. Mirowsky, J.; Ross, C.E. Measurement for a human science. J. Health Soc. Behav. 2002, 43, 152-170. [CrossRef] [PubMed]

32. Thurston-Hicks, A.; Paine, S.; Hollifield, M. Rural Psychiatry: Functional Impairment Associated with Psychological Distress and Medical Severity in Rural Primary Care Patients. Psychiatr. Serv. 1998, 49, 951-955. [CrossRef] [PubMed]

33. Mental Health Commission of Canada. Advancing the Mental Health Strategy for Canada: A Framework for Action (2017-2022). Available online: https:/www.mentalhealthcommission.ca/sites/default/files/ 2016-08/advancing_the_mental_health_strategy_for_canada_a_framework_for_action.pdf2016 (accessed on 23 August 2018).

34. Thomas, S.; Jenkins, R.; Burch, T.; Nasir, L.C.; Fisher, B.; Giotaki, G.; Gnani, S.; Hertel, L.; Marks, M.; Mathers, N.; et al. Promoting Mental Health and Preventing Mental Illness in General Practice. Lond. J. Prim. Care 2016, 8, 3-9. [CrossRef]

35. Caron, J.; Fleury, M.-J.; Perreault, M.; Crocker, A.; Tremblay, J.; Tousignant, M.; Kestens, Y.; Cargo, M.; Daniel, M. Prevalence of psychological distress and mental disorders, and use of mental health services in the epidemiological catchment area of Montreal South-West. BMC Psychiatry 2012, 12, 183. [CrossRef]

36. Torvik, F.A.; Rognmo, K.; Tambs, K. Alcohol use and mental distress as predictors of non-response in a general population health survey: The HUNT study. Soc. Psychiatry Psychiatr. Epidemiol. 2012, 47, 805-816. [CrossRef] [PubMed]

37. Kosidou, K.; Dalman, C.; Lundberg, M.; Hallqvist, J.; Isacsson, G.; Magnusson, C. Socioeconomic status and risk of psychological distress and depression in the Stockholm Public Health Cohort: A population-based study. J. Affect. Disord. 2011, 134, 160-167. [CrossRef]

38. Twomey, C.D.; Baldwin, D.S.; Hopfe, M.; Cieza, A. A systematic review of the predictors of health service utilisation by adults with mental disorders in the UK. BMJ Open 2015, 5, e007575. [CrossRef]

39. Kessler, R.C.; Chiu, W.T.; Demler, O.; Walters, E.E. Prevalence, severity, and comorbidity of 12-month DSM-IV disorders in the National Comorbidity Survey Replication. Arch. Gen. Psychiatry 2005, 62, 617-627. [CrossRef] [PubMed] 
40. De Graaf, R.; ten Have, M.; van Gool, C.; van Dorsselaer, S. Prevalence of mental disorders and trends from 1996 to 2009. Results from the Netherlands Mental Health Survey and Incidence Study-2. Soc. Psychiatry Psychiatr. Epidemiol. 2012, 47, 203-213. [CrossRef] [PubMed]

41. Statistics Canada. Canadian Community Health Survey-Mental Health and Well-Being-Cycle 1.2. 2003. Available online: http://www23.statcan.gc.ca/imdb-bmdi/document/3226_DLI_D1_T22_V2-eng.pdf (accessed on 15 September 2018).

42. Cummins, R.A.; Eckersley, R.; Pallant, J.; Van Vugt, J.; Misajon, R. Developing a national index of subjective well-being: The Australian Unity Well-being Index. Soc. Indic. Res. 2003, 64, 159-190. [CrossRef]

43. Keyes, C.L.M. Mental Illness and/or Mental Health? Investigating Axioms of the Complete State Model of Health. J. Consult. Clin. Psychol. 2005, 73, 539-548. [CrossRef]

44. Keyes, C.L.M. Social well-being. Soc. Psychol. Q. 1998, 61, 121-140. [CrossRef]

45. Andrews, F.M.; Withey, S.B. Social Indicators of Wellbeing: Americans' Perceptions of Life Quality; Plenun Press: New York, NY, USA, 1976.

46. Baker, F.; Intagliata, J. Quality of life in the evaluation of community support systems. Eval. Program Plan. 1982, 5, 69-79. [CrossRef]

47. Kessler, R.C.; Andrews, G.; Mroczek, D.; Üstün, B.; Wittchen, H.-U. The World Health Organization Composite International Diagnostic Interview short-form (CIDI-SF). Int. J. Methods Psychiatr. Res. 1998, 7, 171-185. [CrossRef]

48. Tousignant, M.; Bastien, M.F.; Hamel, S. Suicidal attempts and ideations among adolescents and young adults: The contribution of the father's and mother's care and of parental separation. Soc. Psychiatry Psychiatr. Epidemiol. 1993, 28, 256-261. [PubMed]

49. Gold, L.H. DSM-5 and the assessment of functioning: The World Health Organization Disability Assessment Schedule 2.0 (WHODAS 2.0). J. Am. Acad. Psychiatry Law 2014, 42, 173-181. [PubMed]

50. Vonkorff, M.; Simon, G.; Saunders, K.; Brandenburg, N.; Kessler, R.; Von Korff, M.; Crane, P.; Lane, M.; Miglioretti, D.L.; Stang, P. Chronic spinal pain and physical-mental comorbidity in the United States: Results from the national comorbidity survey replication. Pain 2005, 113, 331-339. [CrossRef]

51. Laurin, I. Facteurs de risque de la condition des sans domicile fixe. In Comparaison d'une Cohorte de Nouveaux Sans Domicile Fixe et d'une Cohorte de Domiciliés Pauvres; Université de Montréal: Montréal, QC, Canada, 1998.

52. Kessler, R.C.; Barker, P.R.; Colpe, L.J.; Epstein, J.F.; Gfroerer, J.C.; Hiripi, E.; Howes, M.J.; Normand, S.-L.T.; Manderscheid, R.W.; Walters, E.E.; et al. Screening for Serious Mental Illness in the General Population. Arch. Gen. Psychiatry 2003, 60, 184-189. [CrossRef]

53. Kay, S.R.; Wolkenfeld, F.; Murrill, L.M. Profiles of Aggression among Psychiatric Patients. J. Nerv. Ment. Dis. 1988, 176, 539-546. [CrossRef] [PubMed]

54. Meadows, G.N.; Burgess, P.; Fossey, E.; Harvey, C. Perceived need for mental health care- findings from the Autralian National Survey of Mental Health and Wellbeing. Psychol. Med. 2000, 30, 645-656. [CrossRef]

55. Kohn, R.; Saxena, S.; Levav, I.; Saraceno, B. The treatment gap in mental health care. Bull. World Heal. Organ. 2004, 82, 858-866.

56. Sagar, R.; Pattanayak, R.D.; Chandrasekaran, R.; Chaudhury, P.K.; Deswal, B.S.; Singh, R.K.L.; Malhotra, S.; Nizamie, S.H.; Panchal, B.N.; Sudhakar, T.P.; et al. Twelve-month prevalence and treatment gap for common mental disorders: Findings from a large-scale epidemiological survey in India. Indian J. Psychiatry 2017, 59, 46-55. [CrossRef]

57. Drapeau, A.; Boyer, R.; Lesage, A. The Influence of Social Anchorage on the Gender Difference in the Use of Mental Health Services. J. Behav. Heal. Serv. Res. 2009, 36, 372-384. [CrossRef] [PubMed]

58. Seekles, W.; Van Straten, A.; Beekman, A.; Van Marwijk, H.; Cuijpers, P. Stepped care treatment for depression and anxiety in primary care. A randomized controlled trial. Trials 2011, 12, 171. [CrossRef] [PubMed]

59. Fleury, M.-J. Implementation of the Consultation-liaison Model in Quebec and its Impact on Primary Care Providers. Ment. Health Fam. Med. 2016, 12, 228-240. [CrossRef]

60. Walters, P.; Tylee, A.; Goldberg, D. Psychiatry in Primary Care. In Essential Psychiatry, 4th ed.; Murray, R.M., Kendler, K.S., McGuffin, P., Wessely, S., Castle, D.J., Eds.; Cambridge University Press: Cambridge, UK, 2008; pp. 479-497. 
61. Fleury, M.J.; Grenier, G.; Bamvita, J.M.; Perreault, M.; Caron, J. Determinants associated with the utilization of primary and specialized mental health services. Psychiatr. Q. 2012, 83, 41-51. [CrossRef] [PubMed]

62. Van Ameringen, M.; Mancini, C.; Patterson, B.; Boyle, M.H. Post-Traumatic Stress Disorder in Canada. CNS Neurosci. Ther. 2008, 14, 171-181. [CrossRef] [PubMed]

63. Erbes, C.; Westermeyer, J.; Engdahl, B.; Johnsen, E. Post-traumatic stress disorder and service utilization in a sample of service members from Iraq and Afghanistan. Mil. Med. 2007, 172, 359-363. [CrossRef] [PubMed]

64. Kuramoto-Crawford, S.J.; Smith, K.E.; McKeon, R. Characteristics of U.S. Mental Health Facilities That Offer Suicide Prevention Services. Psychiatr. Serv. 2016, 67, 119-123. [CrossRef] [PubMed]

65. Mojtabai, R.; Olfson, M.; Mechanic, D. Perceived Need and Help-Seeking in Adults with Mood, Anxiety, or Substance Use Disorders. Arch. Gen. Psychiatry 2002, 59, 77. [CrossRef]

66. Brook, R.; Klap, R.; Liao, D.; Wells, K.B. Mental health care for adults with suicide ideation. Gen. Hosp. Psychiatry 2006, 28, 271-277. [CrossRef] [PubMed]

67. Caron, J.; Liu, A. Factors associated with psychological distress in the Canadian population: A comparison of low-income and non low-income sub-groups. Community Ment. Health J. 2011, 47, 318-330. [CrossRef]

68. Ullman, S.E.; Brecklin, L.R. Sexual Assault History and Suicidal Behavior in a National Sample of Women. Suicide Life Threat. Behav. 2002, 32, 117-130. [CrossRef] [PubMed]

69. Benjet, C.; Borges, G.; Medina-Mora, M.E. Chronic childhood adversity and onset of psychopathology during three life stages: Childhood, adolescence and adulthood. J. Psychiatr. Res. 2010, 44, 732-740. [CrossRef] [PubMed]

70. Glover, K.; Olfson, M.; Gameroff, M.J.; Neria, Y. Assault and Mental Disorders: A Cross-Sectional Study of Urban Adult Primary Care Patients. Psychiatr. Serv. 2010, 61, 1018-1023. [CrossRef] [PubMed]

71. Holman, E.A. Traumatic Life Events in Primary Care Patients: A Study in an Ethnically Diverse Sample. Arch. Fam. Med. 2000, 9, 802-810. [CrossRef] [PubMed]

72. Huỳnh, C.; Caron, J.; Fleury, M.-J. Mental health services use among adults with or without mental disorders: Do development stages matter? Int. J. Soc. Psychiatry 2016, 62, 434-451. [CrossRef] [PubMed]

73. Jorm, A.F.; Christensen, H.; Medway, J.; Korten, A.E.; Jacomb, P.A.; Rodgers, B. Public belief systems about the helpfulness of interventions for depression: Associations with history of depression and professional help-seeking. Soc. Psychiatry Psychiatr. Epidemiol. 2000, 35, 211-219. [CrossRef] [PubMed]

74. Mojtabai, R.; Evans-Lacko, S.; Schomerus, G.; Thornicroft, G. Attitudes Toward Mental Health Help Seeking as Predictors of Future Help-Seeking Behavior and Use of Mental Health Treatments. Psychiatr. Serv. 2016, 67, 650-657. [CrossRef] [PubMed]

75. Ross, L.E.; Vigod, S.; Wishart, J.; Waese, M.; Spence, J.D.; Oliver, J.; Chambers, J.; Anderson, S.; Shields, R. Barriers and facilitators to primary care for people with mental health and/or substance use issues: A qualitative study. BMC Fam. Pr. 2015, 16, 135. [CrossRef] [PubMed]

76. Greenfield, G.; Foley, K.; Majeed, A. Rethinking primary care's gatekeeper role. BMJ 2016, $354,4803$. [CrossRef] [PubMed]

77. Starfield, B.; Lemke, K.W.; Bernhardt, T.; Foldes, S.S.; Forrest, C.B.; Weiner, J.P. Comorbidity: Implications for the Importance of Primary Care in 'Case' Management. Ann. Fam. Med. 2003, 1, 8-14. [CrossRef] [PubMed]

78. Jones, E.; Lebrun-Harris, L.A.; Sripipatana, A.; Ngo-Metzger, Q. Access to Mental Health Services Among Patients at Health Centers and Factors Associated with Unmet Needs. J. Heal. Care Poor Underserved 2014, 25, 425-436. [CrossRef] [PubMed]

79. Jacobson, J.M.; Sacco, P. Employee Assistance Program Services for Alcohol and Other Drug Problems: Implications for Increased Identification and Engagement in Treatment. Am. J. Addict. 2012, 21, 468-475. [CrossRef]

80. Paul, K.I.; Geithner, E.; Moser, K. Latent Deprivation among People who Are Employed, Unemployed, or Out of the Labor Force. J. Psychol. 2009, 143, 477-491. [CrossRef] [PubMed]

81. Buffel, V.; Van De Straat, V.; Bracke, P. Employment status and mental health care use in times of economic contraction: A repeated cross-sectional study in Europe, using a three-level model. Int. J. Equity Heal. 2015, 14, 308. [CrossRef] [PubMed]

82. Jang, Y.; Yoon, H.; Chiriboga, D.A.; Molinari, V.; Powers, D.A. Bridging the Gap Between Common Mental Disorders and Service Use: The Role of Self-Rated Mental Health Among African Americans. Am. J. Geriatr. Psychiatry 2015, 23, 658-665. [CrossRef] 
83. Kim, G.; Jang, Y.; Chiriboga, D.A.; Ma, G.X.; Schonfeld, L. Factors associated with mental health service use in Latino and Asian immigrant elders. Aging Ment. Heal. 2010, 14, 535-542. [CrossRef]

84. Whitley, R.; Wang, J.; Fleury, M.J.; Liu, A.; Caron, J. Mental Health Status, Health Care Utilisation, and Service Satisfaction among Immigrants in Montreal: An Epidemiological Comparison. Can. J. Psychiatry 2017, 62, 570-579. [CrossRef] 